\title{
O PRINCÍPIO DA PROIBIÇÃO DA CONCRETIZAÇÃO DEFICITÁRIA DOS DIREITOS FUNDAMENTAIS E A DECISÃO DO STF NA AFERIÇÃO DO CRITÉRIO DE MISERABILIDADE À CONCESSÃO DE BENEFÍCIO ASSISTENCIAL
}

\author{
THE PROHIBITION OF INSUFFICIENT FUNDAMENTAL \\ RIGHTS PROTECTION PRINCIPLE AND THE BRAZILIAN \\ SUPREME COURT RULING WITH THE CRITERION \\ FOR ASSESSING EXTREME POVERTY IN THE \\ CONTEXT OF SOCIAL SECURITY BENEFITS
}

ANA PAULA MARTINI TREMARIN WEDY ${ }^{1}$

\begin{abstract}
RESUMO: O princípio da proibição da concretização deficitária é importante parâmetro de aferição de constitucionalidade da intermediação legislativa de direitos fundamentais utilizado pelo Supremo Tribunal Federal, o qual consiste no dever, imputável ao Estado, de promover a edição de leis e ações administrativas efetivas para proteger os direitos fundamentais.

PALAVRAS-CHAVE: Direito Fundamental; Benefício Assistencial; Proibição de Proteção Ineficiente.
\end{abstract}

ABSTRACT: The prohibition of insufficient protection principle is an important measurement parameter of the constitutionality of legislative action on fundamental rights used by the Federal Supreme Court, which consists in the duty - imputable to the State - to promote both law enactment and effective administrative action to protect fundamental rights.

KEYWORDS: Fundamental Rights; Social Assistance; Prohibition of Insufficient Protection.

SUMÁRIO: Introdução; 1. ADI 1.232/DF, Reclamação 4374-6/PE, RE 580.963/PR e RE 567985/MT; 2. Direito Fundamental à Assistência Social: perspectiva objetiva; Conclusão; Referências.

Comentário de Jurisprudência recebido em 23.12.2014. Aceito para publicação em 19.01.2015.

${ }^{1}$ Mestranda em Direito na Pontifícia Universidade Católica do Rio Grande do Sul (Porto Alegre), Juíza Federal Substituta. ana.tremarin@trf4.jus.br 
SUMMARY: Introduction; 1. Direct Action of Unconstitutionality (ADI) 1.232/DF, Complaint (RCL) 4374-6/PE, Extraordinary Appeals RE 580.963/PR e RE 567985/MT; 2. Fundamental Right to Social Assistance: objective perspective; Conclusion; References.

\section{INTRODUÇÃO}

O artigo 203, inciso V, da Constituição Federal assegura o benefício assistencial no valor de um salário mínimo a pessoa portadora de deficiência e ao idoso que comprovem não possuir meios de prover à própria manutenção ou de tê-la provida por sua família, conforme dispuser a lei. Nesta esteira, o artigo 20 da Lei no 8.742/93 (Lei de Organização da Assistência Social LOAS) estabeleceu requisitos objetivos e subjetivos para que a pessoa seja considerada idosa ou portadora de deficiência. Define a lei como idoso o indivíduo com idade igual ou superior a 60 (sessenta) anos, e como deficiente a pessoa incapacitada para a vida independente e para o trabalho (art. 20, caput e $\S 2^{\circ}$ ).

O critério subjetivo exige a comprovação da incapacidade da família para prover a manutenção do deficiente ou idoso. Dispõe o art. 20 , § $3^{\circ}$, da Lei 8.742/93: "considera-se incapaz de prover a manutenção da pessoa portadora de deficiência ou idosa a família cuja renda mensal per capita seja inferior a 1/4 (um quarto) do salário mínimo".

O Supremo Tribunal Federal, no julgamento da ADI 1.232-1/DF, em 1998, reconheceu a constitucionalidade do critério de mensuração da renda familiar per capita fixado no $\S 3^{\circ}$ do art. 20 da Lei $n^{\circ} 8.742 / 93 .^{2}$

No julgamento da ADI 1.232-1/DF, o relator, Ministro Ilmar Galvão, proferiu voto vencido no sentido de que o critério legal de aferição de miserabilidade trazia uma presunção juris et de jure, a qual dispensava qualquer tipo de comprovação da necessidade assistencial para as hipóteses de renda familiar per capita inferior a $1 / 4$ do salário mínimo, mas que não excluía a possibilidade

\footnotetext{
2 Dispõe o Art. 203 da CF: "A assistência social será prestada a quem dela necessitar, independentemente de contribuição à seguridade social, e tem por objetivos: (...) $\vee$ - a garantia de um salário mínimo de benefício mensal à pessoa portadora de deficiência e ao idoso que comprovem não possuir meios de prover à própria manutenção ou de tê-la provida por sua família, conforme dispuser a lei." A Ementa da decisão da ADI 1.232-1/DF tem a seguinte redação: "CONSTITUCIONAL. IMPUGNA DISPOSITIVO DE LEI FEDERAL QUE ESTABELECE O CRITÉRIO PARA RECEBER O BENEFÍCIO DO INCISO V DO ART. 203, DA CF. INEXISTE A RESTRIÇÃO ALEGADA EM FACE AO PRÓPRIO DISPOSITIVO CONSTITUCIONAL QUE REPORTA À LEI PARA FIXAR OS CRITÉRIOS DE GARANTIA DO BENEFÍCIO DE SALÁRIO MÍNIMO À PESSOA PORTADORA DE DEFICIÊNCIA FÍSICA E AO IDOSO. ESTA LEI TRAZ HIPÓTESE OBJETIVA DE PRESTAÇÃO ASSISTENCIAL DO ESTADO. AÇÃO JULGADA IMPROCEDENTE" (ADIN- 1.232-1/DF, Tribunal Pleno, 27.08.1998, DJ 10.06.2001, Min. Ilmar Galvão e para o acórdão Min. Nelson Jobim). A Súmula 11 da Turma Nacional de Uniformização, a qual dispunha, "a renda mensal, per capita, familiar, superior a $1 / 4$ (um quarto) do salário mínimo não impede a concessão do benefício assistencial previsto no art. $20 \S 3^{\circ}$ da Lei 8.742 de 1993, desde que comprovada, por outros meios, a miserabilidade do postulante", foi cancelada em 15.05.2006, em virtude da decisão do STF na ADI 1.232/DF.
} 
de comprovação, em concreto e caso a caso, da efetiva falta de meios para que o deficiente ou o idoso possa prover a própria manutenção ou tê-la provida por sua família.

No entanto, prevaleceu o voto do Ministro Nelson Jobim, que considerou que o $\S 3^{\circ}$ do art. 20 da Lei $n^{\circ} 8.742 / 93$ traz um critério objetivo que não é, por si só, incompatível com a Constituição, e que a eventual necessidade de criação de outros requisitos para a concessão do benefício assistencial seria uma questão a ser avaliada pelo legislador.

Não obstante, transcorridos quase 15 anos, o STF reviu sua jurisprudência, e superou seu próprio entendimento, declarando em sede de controle concentrado, a parcial inconstitucionalidade do $\S 3^{\circ}$ do art. 20 da Lei $n^{\circ}$ 8.742/93, sem a declaração de nulidade do dispositivo. ${ }^{3}$

Em que pese o acórdão ainda não ter sido publicado, bem como ainda não haver consenso entre os Ministros sobre a modulação de efeitos desta decisão, o fato é que já são sentidos os efeitos desta decisão paradigmática nos âmbitos administrativo e judicial do país.

O presente estudo analisará a declaração de inconstitucionalidade deste dispositivo à luz do princípio da proibição da concretização deficitária, lastreado nos votos proferidos pelos Ministros Gilmar Mendes e Marco Aurélio no julgamento da Reclamação 4374-6/PE e Recurso Extraordinário 567985/MT.

\section{ADI 1.232/DF, RECLAMAÇÃO 4374-6/PE, RE 580.963/PR E RE 567985/MT}

A alteração da jurisprudência em relação à constitucionalidade do $\S 3^{\circ}$ do art. 20 da Lei $n^{\circ} 8.742 / 93$ iniciou quando os Ministros do STF, em vários julgados monocráticos, deixaram de acolher reclamações formuladas pelo INSS tendentes a fazer valer a autoridade da decisão proferida na ADI 1.232/DF (Rcl 4.374 MC/PE, Rel. Min. Gilmar Mendes, j. 01.02.2007, DJ 06.02.2007, p. 111; Rcl 3.805/SP, Rel. Min. Cármen Lúcia, j. 09.10.2006, DJ 18.10.2006, p. 41;

\footnotetext{
${ }^{3}$ No que tange à técnica da decisão de declaração de inconstitucionalidade sem a pronúncia de nulidade, pertinente citar Gilmar Mendes, in Jurisdição Constitucional: "A declaração de inconstitucionalidade sem a pronúncia de nulidade foi desenvolvida a partir da jurisprudência do Tribunal Constitucional Federal, que na chamada "exclusão do benefício incompatível com o princípio da igualdade", que se verifica quando a lei, de forma arbitrária, concede benefícios a um determinado grupo de cidadãos, excluindo, expressa ou implicitamente, outros segmentos. (...) Ao lado da ofensa ao princípio da igualdade, a omissão legislativa assume relevo para fundamentar a declaração de inconstitucionalidade sem a pronúncia de nulidade na jurisprudência do Tribunal constitucional. A omissão inconstitucional pressupõe um dever constitucional de legislar, que tanto pode ser derivado de ordens concretas contidas na Lei Fundamental quanto de princípios desenvolvidos mediante interpretação. (...) Embora exista, nesse caso, uma lei que poderia ser declarada nula, abstem-se o Tribunal de proferir a nulidade sob a alegação de que a ofensa constitucional decorre não da regulação, mas de sua incompletude, seja porque o legislador foi omisso em proceder à complementação do complexo normativo, seja porque não contemplou determinado grupo na regra impugnada." p. 242-246.
} 
Rcl 4.280/RS, Rel. Min. Sepúlveda Pertence, j. 20.06.2006, DJ 30.06.2006, p. 42; Rcl 4.145/RS, Rel. Min. Marco Aurélio, j. 30.04.2006, DJ 10.05.2006, p. 36). ${ }^{4}$

Nesta perspectiva, o Ministro Gilmar Mendes, no julgamento da Reclamação 4374-6/PE, em decisão monocrática, indefere liminar cautelar, alertando para o fato de que "a necessária reinterpretação do art. 203 da Constituição pode ser reveladora de um processo de inconstitucionalização do $\S 3^{\circ}$ do art. 20 da Lei $n^{\circ} 8.742 / 93$, diante da insuficiência de critérios para se aferir se o deficiente ou o idoso não possuam meios de prover a própria manutenção ou de tê-la provida por sua família, como exige o art. 203, inciso V, da Constituição". 5

O Ministro invoca a dimensão objetiva do direito fundamental à assistência social, ao afirmar que o legislador violou a proibição de proteção insuficiente decorrente deste direito fundamental, gerando um estado de omissão inconstitucional, em que, não obstante a legislação vigente, a proteção legal ocorre de forma insuficiente, porquanto a Lei no 8.742/93 cumpre apenas de forma parcial o comando constitucional. ${ }^{6}$

\footnotetext{
${ }^{4}$ Vide voto vencido do Ministro Teori Zavascki no julgamento do RE 580.963/PR, fls. 27/37. Não obstante, o Plenário, continuava mantendo o que foi decidido na ADI 1.232/DF (v. g.: Rcl-MC-AgR 4.427/RS, Pleno, Rel. Min. Cezar Peluso, j. 06.06.2007, DJ 29.06.2007, p. 23; Rcl 2.323/PR, Pleno, Rel. Min. Eros Grau, j. 07.04.2005, DJ 20.05.2005, p. 8; Rcl-AgR 2.303/RS, Pleno, Rel. Min. Ellen Gracie, j. 13.05.2004, DJ 01.04.2005, p. 5). Disponível em: http://redir.stf.jus.br/paginadorpub/ paginador.jsp?docTP=TP\&docID=4864062. Acesso em: 15 nov. 2014. Neste sentido, no julgamento da Rcl-AgR 2.303/RS, Rel. Min. Ellen Gracie (DJ 01.04.2005), a maioria dos Ministros assentou que, na decisão proferida na ADI 1.232, o Tribunal definiu que o critério de $1 / 4$ do salário mínimo é objetivo e não pode ser conjugado com outros fatores indicativos da miserabilidade do indivíduo e de seu grupo familiar, cabendo ao legislador, e não ao juiz na solução do caso concreto, a criação de outros requisitos para a aferição do estado de pobreza daquele que pleiteia o benefício assistencial.

${ }^{5}$ No que se refere à possibilidade de revisão ou redefinição dos contornos da decisão anteriormente proferida pelo STF em controle abstrato, no âmbito do controle incidental ou difuso de constitucionalidade, Gilmar Mendes enfatiza que o STF por diversas vezes assim o fez, como por exemplo, nas RCL-AgR 2009, Rel. Min. Marco Aurélio, DJ 10.12.2004, na qual o STF fixou os contornos das decisões proferidas nas ADI 1.098 e 1.662, atestando que nelas não se tratou sobre do conceito de precatórios pendentes para efeito de incidência da norma do art. 78 do ADCT (em sentido semelhante, confira-se também o julgamento da RCL-AgR 3.293, Rel. Min. Marco Aurélio, DJ 13.04.2007); e RCL 1.525, Rel. Min. Marco Aurélio, DJ 03.02.2006, na qual o STF delimitou o alcance da decisão proferida na ADI 1.662, especificamente sobre a amplitude do significado de "preterição" de precatórios para fins de seqüestro de verbas públicas. No, entanto, no controle abstrato de constitucionalidade, a oportunidade de reapreciação ou de superação de jurisprudência fica a depender da propositura de nova ação direta contra o preceito anteriormente declarado constitucional, o que será mais raro, dada ao taxativo rol de legitimados ativos e o improvável ressurgimento da questão constitucional, em searas externas aos processos subjetivos, com força suficiente para ser levada novamente ao crivo do STF. Abertura Procedimental, Direitos Fundamentais, Processos Constitucionais Especiais e Técnicas de Decisão. In: Jurisdição Constitucional e Direitos Fundamentais: Interface Portugal/Brasil/ Gilmar Ferreira Mendes e Jorge Miranda (org.). Brasília: IDP, 2014. Disponível no http://www.idp.edu.br/publicacoes/portal-de-ebooks. 125p. Acesso em: 01 dez. 2014.

${ }^{6}$ No que se refere à terminologia "dimensão objetiva dos direitos fundamentais", Ingo Sarlet observa que há diversas outras expressões, tais quais: ordem objetiva de valores, sistema de valores, decisões fundamentais constitucionais, direitos fundamentais como normas objetivas, e que prefere adotar a expressão "perspectiva objetiva dos direitos fundamentais" para evitar
} 
Outrossim, fundamenta o Ministro que a inconstitucionalidade do $\S 3^{\circ}$ do art. 20 da Lei $n^{\circ} 8.742 / 93$ é resultado de um processo de inconstitucionalização decorrente de notórias mudanças fáticas (políticas, econômicas e sociais) e jurídicas (sucessivas modificações legislativas dos patamares econômicos utilizados como critérios de concessão de outros benefícios assistenciais por parte do Estado brasileiro).

Discorre sobre a impossibilidade e inconveniência do Poder Judiciário fixar o critério de mensuração à concessão do benefício assistencial, para ao final, propor que o Supremo Tribunal Federal, no bojo daquela reclamação, revisasse a decisão anteriormente proferida na ADI 1.232 e declarasse a inconstitucionalidade do $\S 3^{\circ}$ do art. 20 da Lei 8.742/93, sem pronúncia da nulidade, de forma a manter-se a sua vigência até o dia 31.12.2014 (dois exercícios financeiros a partir da data em que proferiu o voto). ${ }^{7}$

equívocos relacionados ao termo "dimensões dos direitos fundamentais" como sucedâneo do termo "gerações". p. 148.

7 "Benefício assistencial de prestação continuada ao idoso e ao deficiente. Art. 203, V, da Constituição. A Lei de Organização da Assistência Social (LOAS), ao regulamentar o art. 203, V, da Constituição da República, estabeleceu critérios para que o benefício mensal de um salário mínimo fosse concedido aos portadores de deficiência e aos idosos que comprovassem não possuir meios de prover a própria manutenção ou de tê-la provida por sua família. 2 . Art. $20, \S 3^{\circ}$ da Lei 8.742/93 e a declaração de constitucionalidade da norma pelo Supremo Tribunal Federal na ADI 1.232. Dispõe o art. $20, \S 3^{\circ}$, da Lei $8.742 / 93$ que "considera-se incapaz de prover a manutenção da pessoa portadora de deficiência ou idosa a família cuja renda mensal per capita seja inferior a 1/4 (um quarto) do salário mínimo". O requisito financeiro estabelecido pela lei teve sua constitucionalidade contestada, ao fundamento de que permitiria que situações de patente miserabilidade social fossem consideradas fora do alcance do benefício assistencial previsto constitucionalmente. Ao apreciar a Ação Direta de Inconstitucionalidade 1.232-1/DF, o Supremo Tribunal Federal declarou a constitucionalidade do art. 20, § $3^{\circ}$, da LOAS. 3. Reclamação como instrumento de (re)interpretação da decisão proferida em controle de constitucionalidade abstrato. Preliminarmente, arguido o prejuízo da reclamação, em virtude do prévio julgamento dos recursos extraordinários 580.963 e 567.985 , o Tribunal, por maioria de votos, conheceu da reclamação. O STF, no exercício da competência geral de fiscalizar a compatibilidade formal e material de qualquer ato normativo com a Constituição, pode declarar a inconstitucionalidade, incidentalmente, de normas tidas como fundamento da decisão ou do ato que é impugnado na reclamação. Isso decorre da própria competência atribuída ao STF para exercer o denominado controle difuso da constitucionalidade das leis e dos atos normativos. A oportunidade de reapreciação das decisões tomadas em sede de controle abstrato de normas tende a surgir com mais naturalidade e de forma mais recorrente no âmbito das reclamações. É no juízo hermenêutico típico da reclamação - no "balançar de olhos" entre objeto e parâmetro da reclamação - que surgirá com maior nitidez a oportunidade para evolução interpretativa no controle de constitucionalidade. Com base na alegação de afronta a determinada decisão do STF, o Tribunal poderá reapreciar e redefinir o conteúdo e o alcance de sua própria decisão. $\mathrm{E}$, inclusive, poderá ir além, superando total ou parcialmente a decisão-parâmetro da reclamação, se entender que, em virtude de evolução hermenêutica, tal decisão não se coaduna mais com a interpretação atual da Constituição. 4. Decisões judiciais contrárias aos critérios objetivos preestabelecidos e Processo de inconstitucionalização dos critérios definidos pela Lei 8.742/93. A decisão do Supremo Tribunal Federal, entretanto, não pôs termo à controvérsia quanto à aplicação em concreto do critério da renda familiar per capita estabelecido pela LOAS. Como a lei permaneceu inalterada, elaboraram-se maneiras de contornar o critério objetivo e único estipulado pela LOAS e avaliar o real estado de miserabilidade social das famílias com entes idosos ou deficientes. Paralelamente, foram editadas leis que estabeleceram critérios mais elásticos para concessão de outros benefícios assistenciais, 
Ao final, o voto foi parcialmente acolhido pelos demais Ministros, sendo que a Reclamação foi julgada improcedente e foi declarada a inconstitucionalidade parcial, sem pronúncia de nulidade, do $\S 3^{\circ}$ do art. 20 da Lei 8.742/93, sem que modulasse no tempo os efeitos da decisão por falta de quorum para tanto. ${ }^{8}$

$\mathrm{Na}$ mesma sessão, o STF declara a superação do entendimento consolidado no julgamento da ADI 1.232-1/DF, em sede de controle concentrado, no julgamento dos Recursos Extraordinários (REs) 567985 e 580963/PR, ambos com repercussão geral.

Assim, por maioria de votos, o Plenário do Supremo Tribunal Federal, em 18.04.2013, no julgamento do Recurso Extraordinário 567985/MT declarou a inconstitucionalidade parcial, sem pronúncia de nulidade, do $\S 3^{\circ}$ do art. 20 da Lei 8.742/93, ao fundamento de que o critério para a concessão de benefício a idosos ou deficientes da renda familiar mensal per capita inferior a um quarto do salário mínimo está defasado para caracterizar a situação de miserabilidade. $^{9}$

tais como: a Lei 10.836/2004, que criou o Bolsa Família; a Lei 10.689/2003, que instituiu o Programa Nacional de Acesso à Alimentação; a Lei 10.219/01, que criou o Bolsa Escola; a Lei 9.533/97, que autoriza o Poder Executivo a conceder apoio financeiro a municípios que instituírem programas de garantia de renda mínima associados a ações socioeducativas. O Supremo Tribunal Federal, em decisões monocráticas, passou a rever anteriores posicionamentos acerca da intransponibilidade do critérios objetivos. Verificou-se a ocorrência do processo de inconstitucionalização decorrente de notórias mudanças fáticas (políticas, econômicas e sociais) e jurídicas (sucessivas modificações legislativas dos patamares econômicos utilizados como critérios de concessão de outros benefícios assistenciais por parte do Estado brasileiro). 5. Declaração de inconstitucionalidade parcial, sem pronúncia de nulidade, do art. 20 , § $3^{\circ}$, da Lei 8.742/93. 6. Reclamação constitucional julgada improcedente. (Rcl 4374/PE, Relator: Min. Gilmar Mendes, Julgamento: 18.04.2013, Órgão Julgador: Tribunal Pleno).

${ }^{8} \mathrm{O}$ ministro relator propôs a fixação de prazo para que o Congresso Nacional elaborasse nova regulamentação sobre o tema, mantendo-se a validade das regras questionadas até o dia 31.12.2015. A proposta, embora acolhida por cinco ministros da Corte, não alcançou a adesão de dois terços dos seus integrantes, o que inviabilizou a modulação dos efeitos da declaração de inconstitucionalidade.

9 "Benefício assistencial de prestação continuada ao idoso e ao deficiente. Art. 203, V, da Constituição. A Lei de Organização da Assistência Social (LOAS), ao regulamentar o art. 203, V, da Constituição da República, estabeleceu os critérios para que o benefício mensal de um salário mínimo seja concedido aos portadores de deficiência e aos idosos que comprovem não possuir meios de prover a própria manutenção ou de tê-la provida por sua família. 2 . Art. $20, \S 3^{\circ}$, da Lei 8.742/93 e a declaração de constitucionalidade da norma pelo Supremo Tribunal Federal na ADI 1.232. Dispõe o art. 20, § $3^{\circ}$, da Lei 8.742/93 que "considera-se incapaz de prover a manutenção da pessoa portadora de deficiência ou idosa a família cuja renda mensal per capita seja inferior a 1/4 (um quarto) do salário mínimo". O requisito financeiro estabelecido pela lei teve sua constitucionalidade contestada, ao fundamento de que permitiria que situações de patente miserabilidade social fossem consideradas fora do alcance do benefício assistencial previsto constitucionalmente. Ao apreciar a Ação Direta de Inconstitucionalidade 1.232-1/DF, o Supremo Tribunal Federal declarou a constitucionalidade do art. 20, $\S 3^{\circ}$, da LOAS. 3. Decisões judiciais contrárias aos critérios objetivos preestabelecidos e Processo de inconstitucionalização dos critérios definidos pela Lei 8.742/93. A decisão do Supremo Tribunal Federal, entretanto, não pôs termo à controvérsia quanto à aplicação em concreto do critério da renda familiar per capita estabelecido pela LOAS. Como a lei permaneceu inalterada, elaboraram-se maneiras de se contornar o critério objetivo e único estipulado pela LOAS e de se avaliar o real estado de 
Ainda, no julgamento do RE 580.963/ PR, por maioria de votos, o STF nega provimento ao recurso extraordinário e declara incidenter tantum a inconstitucionalidade parcial, sem pronúncia de nulidade, do parágrafo único do art. 34 da Lei $n^{\circ}$ 10.741/03 (Estatuto do idoso), o qual dispõe que o benefício assistencial já concedido a qualquer membro da família não será computado para fins do cálculo da renda familiar per capita a que se refere o $\S 3^{\circ}$ do art. 20 da Lei $n^{\circ} 8.742 / 93$, sob o argumento de que não há justificativa plausível para a exclusão e consequente discriminação dos portadores de deficiência em relação aos idosos, bem como dos idosos beneficiários da assistência social em relação aos idosos titulares de benefícios previdenciários no valor de até um salário mínimo. ${ }^{10}$

Nestes julgamentos, prevaleceu o entendimento de que em relação à aplicação em concreto do critério da renda familiar per capita estabelecido pela Lei $n^{\circ} 8.742 / 93$, há leis posteriores que estabelecem critérios mais elásticos para concessão de outros benefícios assistenciais, tais como: a Lei 10.836/2004, que criou o Bolsa Família; a Lei 10.689/2003, que instituiu o Programa Nacional de Acesso à Alimentação; a Lei 10.219/2001, que criou o Bolsa Escola; a Lei 9.533/97, que autoriza o Poder Executivo a conceder apoio financeiro a municípios que instituírem programas de garantia de renda mínima associados

miserabilidade social das famílias com entes idosos ou deficientes. Paralelamente, foram editadas leis que estabeleceram critérios mais elásticos para a concessão de outros benefícios assistenciais, tais como: a Lei 10.836/2004, que criou o Bolsa Família; a Lei 10.689/2003, que instituiu o Programa Nacional de Acesso à Alimentação; a Lei 10.219/2001, que criou o Bolsa Escola; a Lei 9.533/97, que autoriza o Poder Executivo a conceder apoio financeiro a Municípios que instituírem programas de garantia de renda mínima associados a ações socioeducativas. O Supremo Tribunal Federal, em decisões monocráticas, passou a rever anteriores posicionamentos acerca da intransponibilidade do critérios objetivos. Verificou-se a ocorrência do processo de inconstitucionalização decorrente de notórias mudanças fáticas (políticas, econômicas e sociais) e jurídicas (sucessivas modificações legislativas dos patamares econômicos utilizados como critérios de concessão de outros benefícios assistenciais por parte do Estado brasileiro). 4. Declaração de inconstitucionalidade parcial, sem pronúncia de nulidade, do art. 20 , § $3^{\circ}$, da Lei 8.742/93. 5. Recurso extraordinário a que se nega provimento". (RE 567985/MT - MATO GROSSO, RECURSO EXTRAORDINÁRIO, Relator(a): Min. Marco Aurélio, Relator(a) p/ Acórdão: Min. Gilmar Mendes, Julgamento: 18.04.2013, Órgão Julgador: Tribunal Pleno)

10 "(...) 4. A inconstitucionalidade por omissão parcial do art. 34, parágrafo único, da Lei 10.741/2003. O Estatuto do Idoso dispõe, no art. 34, parágrafo único, que o benefício assistencial já concedido a qualquer membro da família não será computado para fins do cálculo da renda familiar per capita a que se refere a LOAS. Não exclusão dos benefícios assistenciais recebidos por deficientes e de previdenciários, no valor de até um salário mínimo, percebido por idosos. Inexistência de justificativa plausível para discriminação dos portadores de deficiência em relação aos idosos, bem como dos idosos beneficiários da assistência social em relação aos idosos titulares de benefícios previdenciários no valor de até um salário mínimo. Omissão parcial inconstitucional. 5. Declaração de inconstitucionalidade parcial, sem pronúncia de nulidade, do art. 34, parágrafo único, da Lei 10.741/2003. 6. Recurso extraordinário a que se nega provimento. (RE 580963/PR, Relator(a): Min. Gilmar Mendes, Julgamento: 18.04.2013 Órgão Julgador: Tribunal Pleno, Publicação 14.11.2013). Disponível em: http://www.stf.jus.br/portal/jurisprudencia/listar Jurisprudencia.asp?s1=\%28RE\%24\%2ESCLA\%2E+E+580963\%2ENUME\%2E\%29+OU+\%28RE\% 2EACMS\%2E+ADJ2+580963\%2EACMS\%2E\%29\&base=baseAcordaos\&url=http://tinyurl.com/a9vjb2p. Acesso em: 15 nov. 2014. 
a ações socioeducativas, o que demonstra a defasagem do referencial econômico previsto na lei declarada inconstitucional no particular. ${ }^{11}$

\section{DIREITO FUNDAMENTAL À ASSISTÊNCIA SOCIAL: PERSPECTIVA OBJETIVA}

A Constituição Federal prevê expressamente a existência de direitos fundamentais sociais (artigo $6^{\circ}$ ), especifica seu conteúdo e forma de prestação (artigos 196, 201, 203, 205, 215, 217, entre outros), não faz distinção entre os direitos e deveres individuais e coletivos (capítulo I do Título II) e os direitos sociais (capítulo II do Título II), ao estabelecer que os direitos e garantias fundamentais tem aplicação imediata (artigo $5^{\circ}, \S 1^{\circ}, C F / 88$ ). Desta feita, os direitos fundamentais sociais foram acolhidos pela Constituição Federal de 1988 como autênticos direitos fundamentais. ${ }^{12}$

A Constituição Federal elenca o direito à assistência social e, especificamente o benefício assistencial previsto no artigo 203, inciso V, como um direito fundamental exigível perante o Estado. Esse direito ao benefício assistencial de um salário mínimo possui uma dimensão subjetiva, que o torna um típico direito público subjetivo de caráter positivo, o qual impõe ao Estado obrigações de ordem normativa e fática. Outrossim, obriga o Estado a assegurar as condições normativas (edição de normas e conformação de órgãos e procedimentos) e fáticas (manutenção de um estado de coisas favorável, tais como recursos humanos e financeiros) necessárias à efetividade do direito fundamental. ${ }^{13}$

Assim, os direitos fundamentais possuem dupla faceta: além de uma dimensão subjetiva, apresentam também uma complementar dimensão objetiva. Nessa dimensão objetiva, o direito fundamental à assistência social assume o importante papel de norma constitucional vinculante para o Estado, especificamente, para os Poderes Legislativo, Executivo e Judiciário. Esta dimensão objetiva, impõe ao Legislador o dever constitucional de legislar, o qual deve ser cumprido de forma adequada, segundo os termos do comando normativo previsto no inciso $V$ do art. 203 da Constituição.

\footnotetext{
${ }^{11}$ Vale lembrar que o TRF da $4^{\mathrm{a}}$ Região, já havia consolidado este entendimento na Súmula 6 , (16.11.2004), cujo teor é o seguinte: "O critério de verificação objetiva da miserabilidade correspondente a $1 \frac{1}{4}$ (um quarto) do salário mínimo, previsto no art. 20, $\S 3^{\circ}$, da Lei $n^{\circ} 8.742 / 93$, restou modificado para $1 \frac{1}{2}$ (meio) salário mínimo, a teor do disposto no art. $5^{\circ}$, I, da Lei $n^{\circ}$ 9.533/97, que autorizava o Poder Executivo a conceder apoio financeiro aos Municípios que instituíssem programas de garantia de renda mínima associados a ações socioeducativas, e art. $2^{\circ}$, $\S 2^{\circ}$, da Lei no 10.689/2003, que instituiu o Programa Nacional de Acesso à Alimentação - PNAA".

12 No direito comparado a própria existência de direitos fundamentais sociais é questionada em países cujas Constituições não os prevêem de maneira expressa ou não Ihes atribuem eficácia plena, como, por exemplo, ocorre na Alemanha, cuja Constituição Federal praticamente não contém direitos fundamentais de maneira expressa e também em Portugal, cuja Constituição diferencia o regime constitucional dos direitos, liberdades e garantias do regime constitucional dos direitos sociais.

13 Voto do Ministro Gilmar Mendes no julgamento da Reclamação 4374. Disponível em: http://www.stf.jus.br/arquivo/cms/noticianoticiastf/anexo/rcl4374.pdf. Acesso em: 15 nov. 2014.
} 
O descumprimento total ou parcial desse dever constitucional de legislar acarreta um estado de proteção insuficiente do direito fundamental. O Ministro Gilmar Mendes, em seu voto no julgamento da Reclamação 4374, explicita que: "os direitos fundamentais não contêm apenas uma proibição de intervenção (Eingriffsverbote), expressando também um postulado de proteção (Schutzgebote), e utiliza-se de uma expressão de Canaris, para assentar que não há apenas uma proibição de excesso (Übermassverbot), mas também uma proibição de proteção insuficiente (Untermassverbot)". ${ }^{14}$

O Ministro Gilmar Mendes, inspira-se na jurisprudência da Corte Constitucional alemã, que consolida entendimento no sentido de que do significado objetivo dos direitos fundamentais resulta o dever do Estado não apenas de se abster de intervir no âmbito de proteção desses direitos, mas também de proteger esses direitos contra a agressão ensejada por atos de terceiros. ${ }^{15}$

Relata o Ministro que o entendimento do Tribunal Constitucional alemão confere uma nova dimensão aos direitos fundamentais, fazendo com que o Estado evolua da posição de "adversário" para uma função de guardião dos direitos fundamentais. Assim, a ideia de um dever genérico de proteção fundado nos direitos fundamentais relativiza sobremaneira a separação entre a ordem constitucional e a ordem legal, permitindo que se reconheça uma irradiação dos efeitos desses direitos sobre toda a ordem jurídica. ${ }^{16}$

Enfatiza que, ainda que se não reconheça, em todos os casos, uma pretensão subjetiva contra o Estado, tem-se, inequivocamente, a identificação de um dever deste de tomar todas as providências necessárias para a realização ou concretização dos direitos fundamentais.

Note-se que a invocação deste princípio é recorrente pelo Ministro Gilmar Mendes, como por exemplo, o fez em voto vista, no julgamento do Recurso Extraordinário $418.376 / \mathrm{MS}$, no qual se pretendia extinguir a punibilidade de agente condenado por atentado violento ao pudor, praticado contra uma menina de oito anos, de quem abusou por quatro anos e que, aos doze, engravidou, iniciando, com o seu agressor, uma união estável, para excluir a hipótese de extinção da punibilidade (art. 107, VII, do Código Penal) ao fundamento de que não seria consentâneo com o princípio da proporcionalidade no que toca à proibição de proteção insuficiente.

Enfatizou neste julgamento que a proibição de proteção insuficiente adquire importância na aplicação dos direitos fundamentais de proteção,

\footnotetext{
${ }^{14}$ Disponível em: http://www.stf.jus.br/arquivo/cms/noticianoticiastf/anexo/rcl4374.pdf. Acesso em: 15 nov. 2014.

15 MENDES, Gilmar. Os Direitos Fundamentais e seus Múltiplos Significados na Ordem Constitucional. In: Revista Jurídica, no 14. Brasília, vol. 2, no 13, jun. 1999. p. 5-7. Disponível em: http://www.gilmarmendes.org.br/index.php?option=com_phocadownload\&view=category\&id=9:direitosfundamentais\&Itemid=74. Acesso em: 16 nov. 2014.

16 MENDES, Gilmar. Os Direitos Fundamentais e seus Múltiplos Significados na Ordem Constitucional. In: Revista Jurídica, nº 14. Brasília, vol. 2, nº 13, jun. 1999.
} 
ou seja, na perspectiva do dever de proteção, que se consubstancia naqueles casos em que o Estado não pode abrir mão da proteção do direito penal para garantir a proteção de um direito fundamental. ${ }^{17}$

Ainda, na relatoria do acórdão do julgamento do HC 104410/RS, elucidou que o Tribunal deve sempre levar em conta que a Constituição confere ao legislador amplas margens de ação para eleger os bens jurídicos penais e avaliar as medidas adequadas e necessárias para a efetiva proteção desses bens. Porém, advertiu que apenas quando as medidas legislativas adotadas transbordam os limites impostos pela Constituição, o que poderá ser verificado com base no princípio da proporcionalidade como proibição de excesso (Übermassverbot) e como proibição de proteção deficiente (Untermassverbot), deverá o Tribunal exercer um rígido controle sobre a atividade legislativa, para ao final denegar a ordem ante a constitucionalidade da criminalização do porte de arma.

Outrossim, em voto vencido no julgamento da ADI 3510/DF, que questionava a constitucionalidade das pesquisas científicas com célulastronco embrionárias, o Ministro voltou a invocar em voto vencido a vedação da proteção insuficiente para defender que este dever lastreava uma decisão com eficácia aditiva em que se determinava ao legislador a criação de novo órgão de controle (Comitê Central de Ética e Pesquisa), vinculado ao Ministério da Saúde: "deve-se conferir ao art. $5^{\circ}$ uma interpretação em conformidade com o princípio responsabilidade, tendo como parâmetro de aferição o princípio da proporcionalidade como proibição de proteção deficiente (Untermassverbot). (..) a lei viola o princípio da proporcionalidade como proibição de proteção

${ }^{17}$ O Ministro fundamentou seu voto utilizando-se da doutrina de Lênio Streck e Ingo Sarlet: "Trata-se de entender, assim, que a proporcionalidade possui uma dupla face: de proteção positiva e de proteção de omissões estatais. Ou seja, a inconstitucionalidade pode ser decorrente de excesso do Estado, caso em que determinado ato é desarrazoado, resultando desproporcional o resultado do sopesamento (Abwägung) entre fins e meios; de outro, a inconstitucionalidade pode advir de proteção insuficiente de um direito fundamental-social, como ocorre quando o Estado abre mão do uso de determinadas sanções penais ou administrativas para proteger determinados bens jurídicos. Este duplo viés do princípio da proporcionalidade decorre da necessária vinculação de todos os atos estatais à materialidade da Constituição, e que tem como conseqüência a sensível diminuição da discricionariedade (liberdade de conformação) do legislador."(Streck, Lênio Luiz. A Dupla Face do Princípio da Proporcionalidade: da proibição de excesso (Übermassverbot) à proibição de proteção deficiente (Untermassverbot) ou de como não há blindagem contra normas penais inconstitucionais. Revista da Ajuris, Ano XXXII, $n^{\circ}$ 97, marco/2005, p. 180) No mesmo sentido, o Professor Ingo Sarlet: "A noção de proporcionalidade não se esgota na categoria da proibição de excesso, já que abrange, (...), um dever de proteção por parte do Estado, inclusive quanto a agressões contra direitos fundamentais provenientes de terceiros, de tal sorte que se está diante de dimensões que reclamam maior densificação, notadamente no que diz com os desdobramentos da assim chamada proibição de insuficiência no campo jurídico-penal e, por conseguinte, na esfera da política criminal, onde encontramos um elenco significativo de exemplos a serem explorados."(Sarlet, Ingo Wolfgang. Constituição e Proporcionalidade: o direito penal e os direitos fundamentais entre a proibição de excesso e de insuficiência. Revista da Ajuris, ano XXXII, no 98, jun. 2005, p. 107.) Disponível em: http://www. gilmarmendes.org.br/index.php?option=com_content\&view=article\&id=124\&ltemid=75\#. Acesso em: 16 nov. 2014. 
insuficiente (Untermassverbot) ao deixar de instituir um órgão central para análise, aprovação e autorização das pesquisas e terapia com células-tronco originadas do embrião humano." 18

Da mesma forma, o dever fundamental à proteção suficiente dos direitos sociais, no caso a saúde, foi utilizado no julgamento de suspensão de segurança, em que o Ministro Gilmar Mendes manteve a concessão judicial de medicamentos e tratamentos. ${ }^{19}$

O dever fundamental à vedação da proteção insuficiente também foi um dos fundamentos utilizados pelo Ministro Marco Aurélio, relator do Recurso Extraordinário 567985/MT, para julgar inconstitucional o parâmetro de aferição da miserabilidade de renda familiar per capita inferior a $1 / 4$ do salário mínimo.

O Ministro reitera que os direitos fundamentais tanto possuem uma faceta negativa, que consiste na proteção do indivíduo contra as arbitrariedades provenientes dos poderes públicos, quanto cria deveres de agir. No que tange

\footnotetext{
${ }^{18}$ Sobre a temática, consta na fundamentação do voto do Ministro Gilmar Mendes: Assim, na dogmática alemã é conhecida a diferenciação entre o princípio da proporcionalidade como proibição de excesso (Ubermassverbot) e como proibição de proteção deficiente (Untermassverbot). No primeiro caso, o princípio da proporcionalidade funciona como parâmetro de aferição da constitucionalidade das intervenções nos direitos fundamentais como proibições de intervenção. No segundo, a consideração dos direitos fundamentais como imperativos de tutela (Canaris) imprime ao princípio da proporcionalidade uma estrutura diferenciada. $\mathrm{O}$ ato não será adequado quando não proteja o direito fundamental de maneira ótima; não será necessário na hipótese de existirem medidas alternativas que favoreçam ainda mais a realização do direito fundamental; e violará o subprincípio da proporcionalidade em sentido estrito se o grau de satisfação do fim legislativo é inferior ao grau em que não se realiza o direito fundamental de proteção. $\mathrm{Na}$ jurisprudência do Tribunal Constitucional alemão, a utilização do princípio da proporcionalidade como proibição de proteção deficiente pode ser encontrada na segunda decisão sobre o aborto (BverfGE 88, 203, 1993). O Bundesverfassungsgericht assim se pronunciou: "O Estado, para cumprir com seu dever de proteção, deve empregar medidas suficientes de caráter normativo e material, que levem a alcançar - atendendo à contraposição de bens jurídicos - a uma proteção adequada, e como tal, efetiva (proibição de insuficiência). (...) É tarefa do legislador determinar, detalhadamente, o tipo e a extensão da proteção. A Constituição fixa a proteção como meta, não detalhando, porém, sua configuração. No entanto, o legislador deve observar a proibição de insuficiência (...). Considerando-se bens jurídicos contrapostos, necessária se faz uma proteção adequada. Decisivo é que a proteção seja eficiente como tal. As medidas tomadas pelo legislador devem ser suficientes para uma proteção adequada e eficiente e, além disso, basear-se em cuidadosas averiguações de fatos e avaliações racionalmente sustentáveis.(...)"

${ }_{19}$ Neste sentido, STA $175,211,268,278$, todos de relatoria de Gilmar Mendes. Consta na fundamentação da decisão: "Como tenho analisado em estudos doutrinários, os direitos fundamentais não contêm apenas uma proibição de intervenção (Eingriffsverbote), expressando também um postulado de proteção (Schutzgebote). Haveria, assim, para utilizar uma expressão de Canaris, não apenas uma proibição de excesso (Übermassverbot), mas também uma proibição de proteção insuficiente (Untermassverbot) (Claus-Wilhelm Canaris, Grundrechtswirkungen um Verhältnismässigkeitsprinzip in der richterlichen Anwendung und Fortbildung des Privatsrechts, JuS, 1989, p. 161.). Nessa dimensão objetiva, também assume relevo a perspectiva dos direitos à organização e ao procedimento (Recht auf Organization und auf Verfahren), que são aqueles direitos fundamentais que dependem, na sua realização, de providências estatais com vistas à criação e à conformação de órgãos e procedimentos indispensáveis à sua efetivação. Disponível:http://www.gilmarmendes.org.br/index.php?option=com_content\&view=article\&id=124\& Itemid=75\#. Acesso em: 16 nov. 2014.
} 
à dimensão objetiva dos direitos fundamentais, aduz que um dos seus efeitos é gerar a imposição de deveres permanentes de efetividade, sob pena de censura judicial. Deveras, alude que o artigo $20, \S 3^{\circ}$, da Lei $n^{\circ} 8.742 / 93$, embora não seja inconstitucional, gerou situação concreta de inconstitucionalidade ao deixar de ser suficiente no seu dever de plena e efetiva proteção dos direitos fundamentais, resultante da eficácia positiva de tais direitos, cuja concretização é condição essencial à construção de uma sociedade mais justa e, portanto, civilizada.

O Ministro Marco Aurélio afirma que a concretização do princípio da dignidade humana e do dever específico de proteção dos hipossuficientes, no caso dos idosos e deficientes, não foi regulamentada a contento do que ordena o legislador constituinte, e que o STF deve utilizar, como parâmetro de aferição de constitucionalidade da intermediação legislativa de direitos fundamentais, o princípio da proibição da concretização deficitária, cujo fundamento último radica-se no dever, imputável ao Estado, de promover a edição de leis e ações administrativas efetivas para proteger os direitos fundamentais.

A vedação à proteção insuficiente desponta como uma faceta do princípio da proporcionalidade, o qual tem sua origem vinculada à instituição de um necessário parâmetro para aferir a constitucionalidade das intervenções promovidas pelo Estado nos direitos fundamentais. Desponta, assim, como uma importante ferramenta hermenêutica para fins de controle das ações do Estado potencialmente violadoras de direitos fundamentais. ${ }^{20}$

Assim, o princípio da proporcionalidade apresenta um duplo viés: de proteção positiva e de proteção de omissões estatais. Desta forma, a inconstitucionalidade poderá decorrer do excesso do Estado, caso em que determinado ato é desarrazoado, resultando desproporcional o restado do seu ponderamento entre fins e meios; ou poderá decorrer da proteção insuficiente de um direito fundamental-social. ${ }^{21}$

Nesta perspectiva, o princípio da proporcionalidade também serve de instrumento de aferição da legitimidade das omissões estatais na proteção dos direitos fundamentais, funcionando como um parâmetro para avaliar em que medida o Estado deve agir para efetivar a proteção dos direitos fundamentais. Com efeito, o Estado não poderá frustrar o seu dever de proteção atuando de modo insuficiente, este dever de proteção significa que deverá atender aos níveis mínimos de proteção constitucionalmente exigidos. ${ }^{22}$

\footnotetext{
${ }^{20}$ PEREIRA, Jane Reis Gonçalves. Os Imperativos da Proporcionalidade e da Razoabilidade: Um panorama da discussão atual e da jurisprudência do STF. In Direitos Fundamentais no Supremo Tribunal Federal: balanço e crítica. Daniel Sarmento e Ingo Wolfgang Sarlet. p. 198.

${ }^{21}$ STRECK, Lenio Luiz. A Dupla Face do Princípio da Proporcionalidade e o Cabimento de Mandado de Segurança em Matéria Criminal: superando o ideário liberal-individualista-clássico. Disponível em: https://ensaiosjuridicos.files.wordpress.com/2013/04/a-dupla-face-do-princc3adpioda-proporcionalidade-e-o-cabimento-lenio1.pdf. Acesso em: 25 nov. 2014.

${ }^{22}$ É o que a doutrina e jurisprudência denominam de "proibição de insuficiência", esta denominação seria no sentido de insuficiente implementação dos deveres de proteção do Estado e como tradução livre do alemão Untermassverbot.
} 
Neste contexto, o Estado possui não apenas o dever de não ofender os direitos fundamentais, mas também o dever de atuar positivamente no intuito de proteger estes direitos. Este dever fundamental emana de um dever de proteção advindo dos direitos fundamentais e dele decorre o imperativo categórico à tutela dos direitos sociais.

Com efeito, a jurisprudência do Tribunal Constitucional alemão foi fundamental para o delineamento do dever de proteção do Estado. É emblemática a decisão deste Tribunal em 1979 ao declarar a inconstitucionalidade da Lei de Reforma do Direito Penal, de 18.06.1974, que descriminava o aborto praticado nas primeiras doze semanas da gravidez. O Tribunal Constitucional declarou que o dever de proteção do Estado não só proíbe intervenções diretas estatais na vida em desenvolvimento no ventre materno, como também ordena que o Estado se posicione de forma protetora e fomentadora diante dessa vida, e que a lei que permite o aborto não é apta a cumprir o dever constitucional de proteger, na extensão ordenada (constitucionalmente), a vida em desenvolvimento. ${ }^{23}$

No tocante à jurisprudência do Tribunal Constitucional Federal da Alemanha, Ingo Sarlet afirma que, com base na doutrina de Claus-Wilhelm Canaris e Josef Isensee, aquele Tribunal Constitucional, ao decidir pela segunda vez a questão do aborto, em maio de 1993, considerou que o legislador, ao implementar um dever constitucional de prestação, notadamente no âmbito dos deveres de proteção, está adstrito à proibição de insuficiência, de forma que as medidas estabelecidas pelo legislador deveriam ser suficientes para assegurar um padrão mínimo, adequado e eficaz, de proteção constitucionalmente exigido. Aduz o jurista que a forma mais comum de violação ao princípio da proibição da insuficiência é a omissão do poder público, que pode ser até parcial, no que toca ao dever fundamental de proteção, mas que não é a única, como se depreende no caso de leis de descriminalização de condutas tipificadas, motivo pelo qual não é conveniente o termo "proibição de omissão" ou "proibição por defeito". ${ }^{24}$

Segundo Claus-Wilhelm Canaris os direitos fundamentais possuem diferentes funções, de forma que se prestam primeiramente à defesa de intervenções por parte do Estado nos bens jurídicos de seus cidadãos, e nesta

\footnotetext{
${ }^{23}$ MARTINS, Leonardo (Org). Cinqüenta Anos de Jurisprudência do Tribunal Constitucional Federal Alemão. Montevideo: Fundación Konrad Adenauer, 2006. O autor afirma que os direitos fundamentais à vida e à incolumidade física nasceram, sem precedentes na história constitucional alemã, sob o impactos das atrocidades nazistas. Seu caráter originário era notória e simplesmente de direito de resistência contra a intervenção estatal (Abwehrrecht). Mas o TCF, desde a primeira decisão sobre o aborto (BVerfGE 39, 1) vem desenvolvendo um segundo caráter que deu azo a uma dogmática expandida a outros direitos fundamentais: o caráter de dever de tutela estatal (staatliche Schutzpflicht) em face de agressões provenientes de particulares. Disponível em: http://www.kas.de/wf/doc/kas_7738-544-4-30.pdf . Acesso em: 16 nov. 2014. p. 266-268.

${ }^{24}$ SARLET, Ingo Wolfgang. Constituição e Proporcionalidade: o direito penal e os direitos fundamentais entre a proibição de excesso e de insuficiência. Disponível em: http://www.egov. ufsc.br/portal/sites/default/files/anexos/15113-15114-1-PB.htm. Acesso em: 16 nov. 2014.
} 
perspectiva, são denominados como proibições de intervenção e direitos de defesa em relação ao Estado. Em um segundo aspecto, os direitos fundamentais servem para obrigar o Estado à proteção de seus cidadãos, e nesta seara, são denominados mandamentos de tutela ou deveres de proteção. O jurista alerta que mesmo considerando esta segunda função dos direitos fundamentais, o destinatário permanece o Estado, já que é ao Estado a incumbência do dever de proteção, mas que isto gerará efeitos, por via oblíqua, nas relações interprivadas, já que o Estado está obrigado a proteger um cidadão contra o outro também nas relações entre si. ${ }^{25}$

Para o jurista tedesco a realização da função do imperativo de tutela é a priori possível apenas pela atuação do legislador, que dispõe de um amplo espaço de livre conformação, já que esta função não é constitucionalmente pré-determinada. Reconhece que a realização do imperativo de tutela dos direitos fundamentais também compete ao Poder Judiciário, mas no seu entender, a competência jurisdicional não vai além da competência do legislador, e por isso depende de saber se sobre o legislador recai um correspondente de proteção, que será uma vez constatado, então realizado pela jurisprudência. ${ }^{26}$

Por se tratar de um problema de omissão, é preciso, a priori, fundamentar a existência de um dever jurídico de agir, e assim sendo, Canaris argumenta que a eficácia da função de imperativo de tutela, em combinação com a proibição de insuficiência, é mais fraca que a eficácia da função dos direitos fundamentais como proibições de intervenção, conjugada com a proibição de excesso.

Canaris faz questão de distinguir a proibição de insuficiência com o dever de proteção, e para tanto, explica de forma singela que, na pergunta pelo dever de proteção trata-se do "se" da proteção, ao passo que a proibição de insuficiência tematiza a pergunta pelo "como". Refere que a Constituição impõe apenas a proteção como resultado, mas não a sua conformação específica e que há que ser averiguado apenas se a proteção do direito infraconstitucional é eficaz e apropriada: "é preciso verificar se a proteção satisfaz as exigências mínimas na sua eficiência e se bens jurídicos e interesses contrapostos não estão sobre-avaliados". ${ }^{27}$

Nesta perspectiva, José Carlos Vieira de Andrade, preceitua "particularmente exigente" o entendimento do dever de proteção ao nível da intervenção legislativa. Explica que além das imposições de legislações específicas contidas nos preceitos constitucionais para a proteção dos direitos fundamentais, formula-se ao lado do já tradicional princípio da proibição do excesso e inspirado neste, um princípio de proibição de défice (Untermaberbot), em que

\footnotetext{
${ }^{25}$ CANARIS, Claus-Wilhelm. A Influência dos Direitos Fundamentais sobre o Direito Privado na Alemanha. In: Constituição, Direitos Fundamentais e Direito Privado. Porto Alegre: Livraria do Advogado, 2006. p. 225-245.

${ }^{26}$ CANARIS, Claus-Wilhelm. Direitos Fundamentais e Direito Privado. Tradução de Ingo Wolfgang Sarlet e Paulo Mota Pinto. Coimbra: Almedina, 2012. p. 66.

${ }^{27}$ CANARIS, Claus-Wilhelm. Direitos Fundamentais e Direito Privado. Tradução de Ingo Wolfgang Sarlet e Paulo Mota Pinto. Coimbra: Almedina, 2012. p. 123-125.
} 
o Estado está obrigado a assegurar um nível mínimo adequado de proteção dos direitos fundamentais, sendo responsável pelas omissões legislativas insuficientes a garantirem o cumprimento dessa imposição genérica. ${ }^{28}$

Alerta para a liberdade constitutiva do legislador, e afirma que este conceito de dever de proteção não pode ser radicalizado, que se faz necessário se ater aos limites de fato e de direito, e que em uma sociedade livre e democrática, o legislador deve atuar sabendo que o princípio da proibição do défice vale na medida do possível ${ }^{29}$.

No que se refere à liberdade de conformação do legislador, Alexy, pondera que em uma sociedade democrática, nos casos em que o Judiciário e chamado a resolver lides que envolvam políticas públicas, dever ser prestada deferência à capacidade epistêmica do legislador, isto é, defende que o legislador possui uma margem de ação epistêmica de tipo empírico que lhe permite dizer dos fatos relevantes e dos resultados práticos almejados com a adoção de determinada política pública: "Por el contrario, se trata de un margen de acción epistémico de naturaleza normativa cuando no se tiene la certeza sobre cuál es la manera más apropiada para sopesar los derechos fundamentales que se encuentran en juego, y se reconoce que el Legislador dispone de un determinado marco, dentro del cual puede adoptar una decisión según su propia valoración." ${ }^{30}$

Segundo Alexy, reconhecer que o legislador dispõe de uma margem de ação cognitiva de tipo empírico significa admitir a possibilidade que os direitos fundamentais sejam realizados apenas na medida do possível, de acordo com as possibilidades fáticas. ${ }^{31}$

Canotilho alerta para o fato de que a generalidade da doutrina não reconhece um direito subjetivo dos cidadãos à atividade legislativa: "Embora haja um dever jurídico-constitucional do legislador no sentido de este adotar as medidas legislativas necessárias para tornar exeqüíveis as normas da Constituição, a esse dever não corresponde automaticamente um direito fundamental à legislação". Por esta razão, enaltece a necessidade de institucionalização de formas democráticas tendentes a um maior reforço da proteção jurídica contra omissões inconstitucionais, como são a iniciativa legislativa popular, petições coletivas, ações populares, enfim, formas de acentuação da democracia participativa. ${ }^{32}$

\footnotetext{
${ }^{28}$ ANDRADE, José Carlos Vieira de. Os Direitos Fundamentais na Constituição Portuguesa de 1976. 5. ed., Coimbra: Almedina, 2012. p. 139-140.

${ }^{29}$ ANDRADE, José Carlos Vieira de. Os Direitos Fundamentais na Constituição Portuguesa de 1976. 5. ed., Coimbra: Almedina, 2012. p. 139-140.

${ }^{30}$ ALEXY, Robert. Epílogo a La Teoria de los Derechos Fundamentales. Disponível em: http://epp.di.unito.it/index.php/epp/article/viewFile/85/68?origin=publication_detail. Acesso em: 29 nov. 2014. p. 50-53.

${ }^{31}$ ALEXY, Robert. Epílogo a La Teoria de los Derechos Fundamentales. Op. cit. p. 50-55.

${ }^{32}$ CANOTILHO, J. J. Gomes. Direito Constitucional e Teoria da Constituição. 7. ed., Coimbra: Edições Almedina, 2003. p. 1037.
} 
Ingo Sarlet ao se pronunciar sobre a perspectiva objetiva dos direitos fundamentais, recorda que na doutrina constitucional do primeiro pós-guerra figuram os primeiros contornos do que hoje se considera a dimensão objetiva, mas que somente após a Lei Fundamental de 1949 da Alemanha é que é dado start para o consenso a respeito da existência desta dimensão dos direitos fundamentais. Neste sentido, a decisão da Corte Federal Constitucional proferida em 1958 no paradigmático caso Lüth é decisiva para a formação deste consenso, sendo que a partir desta decisão o mundo consentiu que para além da função precípua de direitos subjetivos de defesa do indivíduo contra atos do poder público, os direitos fundamentais constituem decisões valorativas de natureza jurídico-objetiva na Constituição, com eficácia em todo o ordenamento jurídico e que são diretrizes para os poderes legislativo, executivo e judiciário. ${ }^{33}$

Ingo Sarlet alerta que a perspectiva objetiva dos direitos fundamentais não é um mero "reverso da medalha" da perspectiva subjetiva, ou seja, não significa que qualquer posição jurídica requeira um preceito de direito objetivo antecedente. Admitir a perspectiva objetiva dos direitos fundamentais significa antever que às normas que prevêem direitos subjetivos é outorgada uma função autônoma, a qual requer o reconhecimento de conteúdos normativos e, portanto, de funções diversas aos direitos fundamentais. ${ }^{34}$

Pérez Luno ao escrever sobre a função dos direitos fundamentais no constitucionalismo contemporâneo, refere que estes direitos desempenham uma dupla função: "En el plano subjetivo siguen actuando como garantías de la libertad individual, si bien a este papel clásico se aúna ahora aa defensa de los aspectos sociales y colectivos de la subjetividad, mientras que en el objetivo han asumido una dimensión institucional a partir de la cual su contenido debe funcionalizarse para la consecución de los fines y valores constitucionalmente proclamados." 35

\footnotetext{
${ }^{33}$ SARLET, Ingo Wolfgang. A Eficácia dos Direitos Fundamentais: uma teoria geral dos direitos fundamentais na perspectiva constitucional. 12. ed., Porto Alegre: Livraria do Advogado Editora, 2015. p. 149 Erich Lüth, crítico de cinema e diretor do Clube da Imprensa da Cidade Livre e Hanseática de Hamburgo, conclamou todos os distribuidores de filmes cinematográficos e o público em geral, ao boicote do filme lançado por Veit Harlan, uma antiga celebridade do filme nazista e co responsável pelo incitamento à violência praticada contra o povo judeu (principalmente por meio de seu filme "Jud Süß", de 1941). Harlan ajuizou uma ação cominatória contra Lüth, com base no § 826 BGB, o qual obriga todo aquele que, por ação imoral, causar dano a outrem, a uma prestação negativa, sob cominação de uma pena pecuniária. O Tribunal Estadual de Hamburgo julgou procedente a ação. Lüth interpôs um recurso de apelação junto ao Tribunal Superior de Hamburgo e Reclamação Constitucional no Tribunal Constitucional, alegando violação do seu direito fundamental à liberdade de expressão do pensamento, garantida pelo Art. 5 I 1 GG. O TCF julgou a Reclamação procedente e revogou a decisão do Tribunal Estadual. Ver BVERFGE 7, 198.

${ }^{34}$ SARLET, Ingo Wolfgang. A Eficácia dos Direitos Fundamentais: uma teoria geral dos direitos fundamentais na perspectiva constitucional.

${ }^{35}$ PÉREZ LUÑO, Antonio E. Los Derechos Fundamentales. 11. ed., Madrid: Editorial Tecnos, 2013. p. 21.
} 
A eficácia irradiante dos direitos fundamentais é atribuída à perspectiva objetiva dos direitos fundamentais, e decorre da força jurídica objetiva destes direitos, que passam a exercer a função de fornecer impulsos e diretrizes para a aplicação e interpretação dos direitos fundamentais.

Outrossim, a perspectiva objetiva agrega às funções tradicionalmente reconhecidas aos direitos fundamentais uma espécie de mais-valia jurídica, no sentido de um reforço da juridicidade das normas de direitos fundamentais. Nesta perspectiva, um dos desdobramentos referentes à perspectiva objetivovalorativa dos direitos fundamentais, situa-se a eficácia dirigente que estes geram em relação aos órgãos estatais. Desta feita, estes direitos determinam uma ordem ao Estado para que cumpra sua obrigação permanente de concretização e realização dos direitos fundamentais, aqui incluídos os direitos sociais. $^{36}$

Destarte, em decorrência do princípio da proibição da proteção insuficiente os direitos fundamentais sociais prestacionais não podem ser iludidos pelo Poder Público, seja mediante omissão do dever de implementar as políticas públicas constitucionalmente designadas à realização destes direitos, seja mediante a adoção de políticas públicas inadequadas, ineficientes e insuficientes. ${ }^{37}$

\section{CONCLUSÃO}

A perspectiva objetiva confere aos direitos fundamentais um reforço autônomo de juridicidade, um dever de proteção, pelo qual o legislador está obrigado a atuar para garantir a própria concretização do direito fundamental. Segundo Gilmar Mendes, pode-se ter aqui um autêntico dever constitucional de legislar (Verfassungsauftrag), que obriga o legislador a expedir atos normativos "conformadores" e concretizadores de alguns direitos. ${ }^{38}$

O princípio da proibição da concretização deficitária dos direitos fundamentais, uma das duas vias do princípio da proporcionalidade (excesso e insuficiência), tem lastreado decisões dos Ministros do STF, inclusive no campo de aplicação dos direitos sociais, a exemplo dos Recursos Extraordinários 567.985 e Reclamação 4374, em que o STF declarou que o critério objetivo à concessão de benefício assistencial fixado na Lei 8.742/93, ao regulamentar o art. 203, inciso V, da Constituição Federal, não é suficiente para dotar o direito fundamental à assistência social de plena eficácia.

Note-se que a perspectiva objetiva dos direitos fundamentais, em seu aspecto da proibição de proteção deficiente, ganha nota de indispensabilidade

\footnotetext{
${ }^{36}$ SARLET, Ingo Wolfgang. Constituição e Proporcionalidade: o direito penal e os direitos fundamentais entre a proibição de excesso e de insuficiência. Disponível em: http://www.egov. ufsc.br/portal/sites/default/files/anexos/15113-15114-1-PB.htm. Acesso em: 16 nov. 2014.

${ }_{37}$ ROCHA, Daniel Machado da; SAVARIS, José Antônio. Curso de Direito Previdenciário: fundamentos e aplicação do Direito Previdenciário. Curitiba: Alteridade Editora, 2014. p. 127-128.

${ }_{38}$ MENDES, Gilmar. Os Direitos Fundamentais e seus Múltiplos Significados na Ordem Constitucional. In: Revista jurídica, $n^{\circ} 14$, Brasília, vol. 2, n 13, jun. 1999. p. 5-7. Disponível em: http://www.gilmarmendes.org.br/index.php?option=com_phocadownload\&view=category\&id=9:direitosfundamentais\&Itemid=74. Acesso em: 16 nov. 2014.
} 
na tutela dos direitos sociais e pode ser considerada principal argumento suficiente até para derrogar entendimento consagrado há mais de quinze anos no STF, como ocorreu no caso da interpretação constitucional emprestada ao artigo 20 , § $3^{\circ}$, da Lei $n^{\circ} 8.742 / 93$.

A Constituição Federal defere ao legislador ordinário amplas margens de avaliação e de decisão, de forma que compete ao Poder Legislativo a definição de quais as medidas mais adequadas e necessárias para a efetiva proteção de determinado bem jurídico. Deveras, o espaço de conformação do legislador para o cumprimento de seu dever de proteção aos direitos fundamentais é inquestionável, porquanto o dever constitucional de proteção não exige a adoção de todas as possíveis e imagináveis medidas de proteção, na medida em que uma violação do dever de proteção pode ser reconhecida quando nenhuma medida concreta e adequada é tomada ou as medidas forem inteiramente inadequadas ou ineficazes. ${ }^{39}$

Nada obstante, a liberdade de conformação legislativa não é ilimitada, de forma que está adstrita materialmente à previsão constitucional, sendo certo que a jurisprudência do STF admite que a violação dos Poderes Legislativo e Executivo ao princípio da proibição da proteção deficiente autoriza a intervenção do Poder Judiciário para que seja garantida a necessária, adequada e suficiente tutela dos direitos fundamentais.

Sem embargo, necessária se faz o delineamento da abrangência e âmbito de incidência da vedação da proteção insuficiente, porquanto este princípio representa um instrumento estimulador à progressão de um ativismo judicial ao possibilitar uma maior interferência do Poder Judiciário no âmbito de conformação do Poder Legislativo e Executivo.

Neste contexto, este princípio consagrador do controle constitucional das omissões, ainda que parciais, do legislador deverá ser invocado em ultima ratio, em observância ao dogma da separação de poderes e o princípio da reserva do financiamento possível, isto é, deve ser reservada sua aplicação para hipóteses de manifesta violação do dever fundamental de proteção. ${ }^{40}$

\footnotetext{
39 SARLET, Ingo Wolfgang. Constituição e Proporcionalidade: o direito penal e os direitos fundamentais entre a proibição de excesso e de insuficiência. Disponível em: http://www.egov. ufsc.br/portal/sites/default/files/anexos/15113-15114-1-PB.htm. Acesso em: 16 nov. 2014.

${ }^{40}$ PEREIRA, Jane Reis Gonçalves. Os Imperativos da Proporcionalidade e da Razoabilidade: Um panorama da discussão atual e da jurisprudência do STF. In Direitos Fundamentais no Supremo Tribunal Federal: balanço e crítica. Daniel Sarmento e Ingo Wolfgang Sarlet. p. 199. No que se refere à abordagem jurídica dos direitos sociais, pertinente trazar à tona trecho do pensamento de Canotilho: "paira sobre a dogmática e teoria jurídica dos direitos econômicos, sociais e culturais a carga metodológica da vaguidez, indeterminação e impressionismo que a teoria da ciência vem apelidando, em termos caricaturais, sob a designação de 'fuzzismo' ou 'metodologia fuzzy'”. "Em toda a sua radicalidade a censura de fuzzysmo lançada aos juristas significa basicamente que eles não sabem do que estão a falar quando abordam os complexos problemas dos direitos econômicos, sociais e culturais" (CANOTILHO, J. J. Gomes. Metodologia "fuzzy" e "camaleões normativos" na problemática actual dos direitos econômicos, sociais e culturais. In: Estudos sobre Direitos Fundamentais. Coimbra: Coimbra Editora, 2004, p. 100).
} 
Por fim, a deferência à liberdade de conformação do legislador não legitima a conservação parcial de uma norma inconstitucional, a menos que, como na hipótese das decisões do STF analisadas, a declaração de nulidade da lei que não mais atende ao mínimo necessário à proteção de um direito fundamental como o direito à assistência social, resultar no vácuo legislativo intolerável para a ordem constitucional.

\section{REFERÊNCIAS}

ALEXY, Robert. Epílogo a la Teoria de los Derechos Fundamentales. Disponível em: http://epp.di.unito.it/index.php/epp/article/viewFile/85/68?origin=publication_detail. Acesso em: 29 nov. 2014.

ANDRADE, José Carlos Vieira de. Os Direitos Fundamentais na Constituição Portuguesa de 1976. 5. ed., Coimbra: Almedina, 2012.

CANARIS, Claus-Wilhelm. A Influência dos Direitos Fundamentais sobre o Direito Privado na Alemanha. In: Constituição, Direitos Fundamentais e Direito Privado. Porto Alegre: Livraria do Advogado, 2006.

CANARIS, Claus-Wilhelm. Direitos Fundamentais e Direito Privado. Tradução de Ingo Wolfgang Sarlet e Paulo Mota Pinto. Coimbra: Almedina, 2012.

CANOTILHO, J. J. Gomes. Direito Constitucional e Teoria da Constituição. 7. ed., Coimbra: Edições Almedina, 2003.

MARTINS, Leonardo (Org). Cinqüenta Anos de Jurisprudência do Tribunal Constitucional Federal Alemão. Montevideo: Fundación Konrad Adenauer, 2006. Disponível em: http://www.kas.de/wf/doc/kas_7738-544-4-30.pdf . Acesso em: 16 nov. 2014.

MENDES, Gilmar Ferreira. Abertura Procedimental, Direitos Fundamentais, Processos Constitucionais Especiais e Técnicas de Decisão. In: Jurisdição Constitucional e Direitos Fundamentais: Interface Portugal/Brasil/ Gilmar Ferreira Mendes e Jorge Miranda (org.). Brasília: IDP, 2014. Disponível no http://www.idp.edu.br/publicacoes/portal-deebooks. Acesso em: $01 \mathrm{dez} .2014$.

. Jurisdição Constitucional: o controle abstrato de normas no Brasil e na Alemanha. 4. ed., São Paulo: Saraiva, 2004.

Os Direitos Fundamentais e seus Múltiplos Significados na Ordem Constitucional. In: Revista Jurídica, $\mathrm{n}^{\circ}$ 14. Brasília, vol. 2, $\mathrm{n}^{\circ}$ 13, jun. 1999. Disponível em: http://www.gilmarmendes.org.br/index.php?option=com_phocadownload\&view=category \&id=9:direitos-fundamentais\&ltemid=74. Acesso em: 16 nov. 2014.

PEREIRA, Jane Reis Gonçalves. Os Imperativos da Proporcionalidade e da Razoabilidade: Um panorama da discussão atual e da jurisprudência do STF. In Direitos Fundamentais no Supremo Tribunal Federal: balanço e crítica. Daniel Sarmento e Ingo Wolfgang Sarlet.

PÉREZ LUÑO, Antonio E. Los Derechos Fundamentales. 11. ed., Madrid: Editorial Tecnos, 2013.

ROCHA, Daniel Machado da; SAVARIS, José Antônio. Curso de Direito Previdenciário: fundamentos e aplicação do Direito Previdenciário. Curitiba: Alteridade Editora, 2014.

SARLET, Ingo Wolfgang. A Eficácia dos Direitos Fundamentais: uma teoria geral dos direitos fundamentais na perspectiva constitucional. 12. ed., Porto Alegre: Livraria do Advogado Editora, 2015. 
SARLET, Ingo Wolfgang. Constituição e Proporcionalidade: o direito penal e os direitos fundamentais entre a proibição de excesso e de insuficiência. Disponível em: http://www.egov.ufsc.br/portal/sites/default/files/anexos/15113-15114-1-PB.htm. Acesso em: 16 nov. 2014.

STRECK, Lenio Luiz. A Dupla Face do Princípio da Proporcionalidade e o Cabimento de Mandado de Segurança em Matéria Criminal: superando o ideário liberal-individualistaclássico. Disponível em: https://ensaiosjuridicos.files.wordpress.com/2013/04/a-duplaface-do-princc3adpio-da-proporcionalidade-e-o-cabimento-lenio1.pdf. Acesso em: 25 nov. 2014. 